\title{
Food Processing Characteristics of Water Yam (Dioscorea alata) and Cowpea (Vigna unguiculata) Flour Blend Used Locally for Production of Concessionaries
}

\author{
Nwafor J. O ${ }^{1, *}$, Ezeocha V. C ${ }^{2}$, C Kanu A. C ${ }^{1}$, Onyebula O. D \\ ${ }^{1}$ National Root Crops Research Institute, Nigeria \\ ${ }^{2}$ Michael Okpara University of Agriculture, Nigeria
}

Copyright $C 2019$ by authors, all rights reserved. Authors agree that this article remains permanently open access under the terms of the Creative Commons Attribution License 4.0 International License

\begin{abstract}
The performance of blends of water yam (Dioscorea alata) and cowpea (Vigna unguiculata) flours for preparation confectionaries was investigated. Water yam and cowpea were processed into flours and $100 \%$ water yam flour served as the control sample. However, water yam cake, chinchi and bread were produced using water yam flour and cowpea flour which were blended at different ratio (ie. 100\%:0, 90:10, 80:20, 70:30, 60:40 and $50: 50$ ). The proximate analysis and functional properties of the water yam-cowpea flour were determined. The sensory evaluation showed that samples 50:50, 60:40 and 70:30 were the most acceptable because they contained little quantity of cowpea flour. The scores obtained for overall acceptability of the confectionaries ranged from extremely dislike to extremely like, indicating that the cake samples were generally liked by the panelists. This study showed that the panelists like the sample 50:50 more than the other samples. Therefore, the cowpea fortified yam flour could contribute to quality protein intake in populations consuming yam as a staple, due to its indispensible amino acid content.
\end{abstract}

Keyword Water Yam, Cowpea, Water Yam Cowpea Blends, Confectionary

\section{Introduction}

Yam (Dioscorea spp.) is an elite crop, preferred over other root and tuber crops in West Africa, the leading producer of yams. Yam is estimated to feed millions of people and is extremely important for at least 60 million people comprising rural producers, processors and consumers in West Africa (Adebowale, A.A, 2005). Apart from serving as food, yam has a lot of potential industrial uses but unfortunately has not been commercially processed to any significant extent. Dioscorea alata is one of the six yam species of economic importance but in Nigeria, it is less utilized for major food products as a result of traditional bias which fails to recognize the unique quality characteristics and the good agronomic flexibility of the species. The species has high yield, high multiplication ratio and better tuber storability, than the preferred indigenous $D$. rotundata. $D$. alata has an advantage for sustainable cultivation especially when yam production seems to be on the decline as a result of high cost of production, low yields and post harvest losses among others

In most developing countries including Nigeria, the economic situation is such that the low income families cannot afford protein rich foods from animal source to meet recommended dietary allowance. The diet of most people consists predominantly of cereals and roots which do not provide good quality protein in diet. Studies by the food and Agricultural organization have shown that over one billion people are undernourished in the world (Onwuka G. I 2007). One way to curb the global menace is through food enrichment or fortification of legumes and tuber crops Hoover, R. (2001).

Fortification refers to the practice of deliberately increasing the content of essential nutrients in a food irrespective of whether the nutrients were originally in the food before processing or not, so as to improve the nutritional quality of the food supply and to provide a public health benefit with minimal risk to health.

However, because of the low protein content of Dioscorea spp. Onayemi O. (1974) protein - energy malnutrition is prevalent in rural populations where yam is a staple especially among women and children Adamson I. (198). Therefore, improving the nutritional quality of yam flour through fortification using a protein rich source will contribute in improving the nutrition status of women and children. 
Cake,chinchin, and bread is popular food in Nigeria and other West African Countries Ngoddy P.O, (1986), Henshaw F.O, (1996), Ekariko P, (2005) and form part of diet for most ethnic groups in Nigeria. Nigerians usually eat it as breakfast or lunch or even dinner. Chinchin is a traditional African food made by deep frying cowpea paste that has been whipped and seasoning with sugar, and other optional ingredients. The outer crust of cake is crisp and the interior is spongy like bread. It is considered to be the most commonly consumed cowpea based food in West Africa Ugwu F.M.(2009), Asare A.T, (2013), Seeds of cowpea can be cooked in the dried form, sprouted or ground into flour in intermediate product. Being in the class of legumes, they are often referred to as poor man's meat'due to their use as primary protein sources Odedeji J.O, (2011). It is an important dietary staple in West African countries because of its high nutritional value, low cost and broad availability in the region. Legumes are valuable source of proteins, hence blends of tubers and legume diet will satisfy both the protein and carbohydrate requirements of man.

\section{Material and Methods}

\subsection{Sample Collection}

D. alata, were obtained from Izzi Local Government Area of Ebonyi State, Nigeria. The yam tubers will be carefully selected to avoid rot, bruises or sign of spoilage. Cowpea (Vigna ungiuculata) and other ingredients was also purchased from Eke market in Ebonyi State.

\subsection{Preparation of Blends of Water Yam and Cowpea}

Different ratios of water yam and cowpea flours will be formulated ranging from 90:10, 80:20, 70:30, 60:40 and 50:50 respectively. 100 percent water yam flour served as control sample, the samples will be represented with the codes $\mathrm{A}, \mathrm{B}, \mathrm{C}, \mathrm{D}, \mathrm{E}$ and $\mathrm{F}$ respectively

\subsection{Preparation of Water Yam Flour}

Standard procedure for the preparation of instant yam flour will be used for the production of water yam flour as described by Olu M.A, (2012). Water yam tuber will manually peeled with a sharp stainless knife and cut into thin slices so as to ensure efficient heat circulation during blanching and drying. Slices will be washed, in order to prevent browning of the yam slices. Yam slices will be drained and rapidly blanched at $100^{\circ} \mathrm{C}$ for $5 \mathrm{~min}$. The pre-cooked yam slices will be dried at $60^{\circ} \mathrm{C}$ for $24 \mathrm{hr}$. The dried yam slices will be milled and packaged in polythene bag.

\subsubsection{Preparation of Water Yam Flour}

$$
\begin{aligned}
& \text { Fresh tuber } \\
& \int \\
& \text { peeling } \\
& \Omega \\
& \text { Washing } \\
& \Omega \\
& \text { Chipping (size reduction) } \\
& \Omega \\
& \text { Conditioning }\left(50-70^{\circ} \mathrm{C}\right) \\
& \Omega \\
& \text { Steeping / fermentation }(24 \mathrm{hrs}) \text { optional } \\
& \Omega \\
& \text { Decantation } / \text { drained } \\
& \Omega \\
& \text { Oven dry }\left(60-70^{\circ} \mathrm{C} 24 \mathrm{hrs}\right) \\
& \Omega \\
& \text { Milling }(0.5 \mathrm{~mm}-1 \mathrm{~mm} \text { sieves) } \\
& \Omega \\
& \text { Water yam flour } \\
& \Omega \\
& \text { Packaged yam flour }
\end{aligned}
$$

Figure 1. Flow chat production of water yam flour

\subsubsection{Preparation of Cowpea}

$$
\begin{gathered}
\text { Shelled cowpea } \\
\Omega \\
\text { Soaking / 30mins } \\
\Omega \\
\text { Dehulling/ winnowing } \\
\Omega \\
\text { Oven dry } 60 / 24 \mathrm{hrs} \\
\Omega \\
\text { Mill } \\
\Omega \\
\text { Sieving } / 0.05 \\
\Omega \\
\text { Cooling } \\
\Omega \\
\text { Packaging } \\
\Omega \\
\text { Storage }
\end{gathered}
$$

Source :Udensi E. A (2008)

Figure 2. Flow chat production of cowpea flour

\subsubsection{Proximate Analysis of Flours}

Determination of Moisture Content: The method described by AOAC (2005) was used.

Determination of Ash content: The method described by AOAC (2005) was used.

Determination of Crude Fat: The method described by AOAC (2000) was used.

Determination of Protein: The method described by AOAC (2000) was used.

Determination of Fibre: The method described by AOAC (2000) was used.

Determination of Carbohydrates: The method described by AOAC (2000) was used.

\subsubsection{Functional Properties of Flours}

Water Absorption capacity: The procedure described by Sosulski (1962) was used.

Fat Absorption Capacity: The procedure described by Lin et al. (1974) was used. 
Bulk Density: The procedure described by Fellows 2000 was used.

Swelling Power Solubility: The procedure described by AOAC (2000) was used.

\section{Results and Discussion}

\subsection{Proximate Composition of Water Yam Cowpea Flour}

The moisture content ranged from $8.60+0.14$ to $12.75+0.64$ with the highest value observed in the water yam/ cowpea flour containing 50:50 blends. This is probably due to the high content of water yam fiber that has the ability to imbibe moisture from the environment and swell water yam has been shown to have hygroscopic or water absorbing properties (Karuna, D., et al 1996). The low moisture content generally observed in the sample may add the adverntage or prolonging the shelf life of the products, if properly packaged

The protein content of the sample ranged from 9.03+ 0.01 to $19.63+0.54$. the high protein content of the products may be attributed to the presence of cowpea flour used in the formulations. Raw cowpea has been reported to contain about $19-21 \%$ protein (Chou, D. H. et al 1979). The progressive solubilization and leaching out of the nitrogenous substances during soaking and boiling of the legume may be responsible for the slight protein reduction in the samples (Kordylas, J. M. 1990) other than these, the general high level of protein, however demonstrates the effect of supplementing legume in water yam.

The result of the analysis show that the fat content of the formulate water yam were generally low, ranging from $0.03+0.01$ to $0.14+\ldots 0.01$. The presence cowpea in formulation with water yam is responsible for the generally low fat content of the resulting products, although most of the legumes, with the exception of groundnuts and soybeans contain less than 3\% fat (Ihekoronye and Ngoddy, 1985).

The value obtained the determination of crude fiber content of the formulated water yam and cowpea flour ranged from $0.46+0.01$ to $1.95+0.05$. Higher value were recorded 3.1-3.8\% (Egounlety $\overline{\mathrm{M}} ; 2002$ ) and $1.54-4.0 \%$ Sosulki, F.W (1962), fiber is needed to assist in digestion and keep the gastrointestinal tract healthy and can also help to keep the blood sugar stable. It slows down the release of glucose during digestion. So cells require less insulin to absorb that glucose. The American diabetes Association recommends that people with diabetes should consume 25$50 \mathrm{~g}$ of fiber per day FAO (2000). The fecal bulking action of insoluble fiber makes it useful in the treatment of constipation and diverticular disease (Shanthakumari. S., et al 2008).

The results of the ash content analysis of the formulated sample showed significant different $(p \leq 0.05)$ with values ranging from $0.79+0.01$ to $3.54+0.05$ lower values $1.36+0.05 \%$ (Egounlety $\mathrm{M} ; 2002$ ) and $1.50-2.50 \%$ Sosulki, F.W (1962) were recorded by other researchers.

The values from the carbohydrate content analysis of the formulated samples ranged from $63.75+0.81$ to $81.38+0.28$. There is significant different $(\mathrm{p} \leq 0.05)$. Higher carbohydrate value was reported for water yam formulated at 50:50\% Sosulki, F.W (1962). The higher carbohydrate values recorded by other researchers may be attributed to the higher content of the water yam and cowpea blends. ( Sanni A.I. et al, 2001)

The values obtained for the total energy content of the formulated samples raging from $333+\_1.01$ to $367+\_1.08$ were found to be within the range value of $314-420 \mathrm{kcal}$ (Sosulki, F.W 1962), (Ragaee S. et al 2006). These value represent the amount of energy in food that can be supplied to the body for maintenance of basic body function such as breathing, circulation of blood, physical activities and thermic effect of food. Increasing addition of coconut fiber was inversely proportional to the energy value of the products.

Table 1. Proximate Composite of the water yam

\begin{tabular}{cccccccc}
\hline Sample & Moisture (\%) & Ash (\%) & Fibre (\%) & Fat (\%) & Protein (\%) & CHO (\%) & Energy(kcal) \\
\hline A & $7.18^{\mathrm{e}}+0.28$ & $0.79^{\mathrm{f}}+0.01$ & $1.95^{\mathrm{a}}+0.05$ & $0.14^{\mathrm{b}}+0.20$ & $9.03^{\mathrm{d}}+0.44$ & $81.38^{\mathrm{c}}+0.28$ & $367^{\mathrm{a}}+1.08$ \\
\hline B & $8.48^{\mathrm{d}}+0.48$ & $1.93^{\mathrm{e}}+0.23$ & $1.49^{\mathrm{c}}+0.01$ & $0.03^{\mathrm{d}}+0.71$ & $11.06^{\mathrm{d}}+0.09$ & $78.36^{\mathrm{a}}+2.18$ & $350^{\mathrm{a}}+3.26$ \\
\hline C & $7.45^{\mathrm{e}}+0.23$ & $2.15^{\mathrm{d}}+0.23$ & $1.34^{\mathrm{d}}+0.03$ & $0.03^{\mathrm{d}}+0.04$ & $12.16^{\mathrm{c}}+0.31$ & $73.98^{\mathrm{b}}+0.40$ & $352^{\mathrm{a}}+1.09$ \\
\hline D & $9.02^{\mathrm{c}}+0.06$ & $2.47^{\mathrm{c}}+0.32$ & $1.23^{\mathrm{e}}+0.02$ & $0.09^{\mathrm{a}}+0.04$ & $13.84^{\mathrm{b}}+0.75$ & $71.04^{\mathrm{d}}+0.39$ & $348^{\mathrm{a}}+0.18$ \\
\hline E & $11.50^{\mathrm{b}}+0.42$ & $2.48^{\mathrm{b}}+0.18$ & $0.46^{\mathrm{f}}+0.01$ & $0.07^{\mathrm{a}}+0.11$ & $19.53^{\mathrm{a}}+0.13$ & $68.74^{\mathrm{a}}+0.97$ & $338^{\mathrm{a}}+0.18$ \\
\hline F & $12.75^{\mathrm{a}}+0.28$ & $3.54^{\mathrm{a}}+0.05$ & $1.73^{\mathrm{b}}+0.18$ & $0.10^{\mathrm{c}}+0.18$ & $19.63^{\mathrm{a}}+0.54$ & $63.75^{\mathrm{a}}+0.81$ & $333^{\mathrm{a}}+1.01$ \\
\hline
\end{tabular}

Means are \pm standard deviation of duplicate determination. Means with the same superscript within the same column are not significantly different $(\mathrm{P}>0.05)$.

Where:

A: $100 \%$ water yam flour

B: $90 \%$ water yam flour, $10 \%$ cowpea flour

C: $80 \%$ water yam flour, $20 \%$ cowpea flour

D: $70 \%$ water yam flour, $30 \%$ cowpea flour

E: $60 \%$ water yam flour, $40 \%$ cowpea flour

F: $50 \%$ water yam flour, $50 \%$ cowpea flour 


\subsection{Functional Properties}

\subsubsection{Bulk Density}

The result of bulk density of the blends ranged from $0.61+0.01$ to $0.76+0.02 \mathrm{~g} / \mathrm{ml}$ with the highest value found in the sample with 90:10 formulations. There was a gradual reduction of the bulk density with increase in the addition of the cowpea flour, except sample 100:0 which have $0.74 \pm 0.01^{\mathrm{c}}$.Although the sample with $80: 10$ and 70:30 formulations did not have significant differences $(\mathrm{p} \geq 0.05)$. Higher values of bulk density $(2.45 \pm 0.10$ and $2.60 \pm 0.05$ ) were recorded by (Egounlety M; 2002) the bulk density of the product may require identical packaging space. The less the bulk density the more packaging space is required (Egounlety M; 2002).

The Water Absorption Capacity of the water yam-cowpea flour blend ranged from 2.09+_0.03 to 2.67+_0.14 in which sample B had the highest valued while sample $\mathrm{D}$ had the lowest valued of $2.09+0.03$.it was found to decrease with increase of cowpea flour inclusion. This may be connected to the fact that water yam fiber has hygroscopic properties, thus, swelling on exposure to moisture (Karuna, D., et al 1996).

Swelling power of the varieties ranged from $0.93 \pm 0.01$ to $0.93 \pm 0.01 \%$. water yam blend, the reference variety had significantly $(\mathrm{p}<0.05)$ higher value of $12.06 \%$. D. roundata is known to have higher swelling power in comparison to other species of yam (Baah et al., 2009; Walter et al., 2000) as observed in this study. Swelling power is largely controlled by the strength and character of the micellar network within starch granules. Thus, the lower swelling power values obtained for the test varieties could be as a result of highly ordered internal arrangement in their starch granules.
The oil absorption capacity Of the blend flour varied intrend from those obtained for water absorption capacity. The values ranged from $0.61+0.01-0.74+[0.01$ with the highest value recorded for the sample 50:50 formulations. The hydrophobicity of protein is known to play a major role in fat absorption. This acts to resist physical entrapment of oil by the capillary of non-polar side chain of the amino acids of the protein molecules (Kulkarni, K. D $1991)$ there were significant differences $(p \leq 0.05)$ among all the samples.

\subsubsection{Sensory Evaluation}

The sensory evaluation showed no significant differences in the colour of samples A, B, C and D but there was significant difference in samples $\mathrm{E}$ and $\mathrm{F}$ ranging from golden brown to light brown. The details of these are shown in Table 3. The colour became lighter with substitution with higher ratio of cowpea compared to samples B, C and D which had lower ratios of cowpea flour. The texture of samples $\mathrm{A}$ and $\mathrm{C}$ was not significantly different, while samples B and D had the same texture compared to samples $\mathrm{E}$ and $\mathrm{F}$ which had different textures form all other samples. The flavors of samples A, B, C and D were not significantly different from each other but samples $\mathrm{E}$ and $\mathrm{F}$ are significantly different from each other. This is due to the different high ratios of cowpea flour that each of them contained. The taste of A, B, C and D were not significantly different from each other. They contained lesser quantity of cowpea flour but with the exception of A which had no cowpea flour. Conclusively, samples B, C, D were the most acceptable samples. This is due to the fact that they contain little ratio of cowpea flour, having the highest mean in flavor, taste, texture, colour and general acceptability .

Table 2. Functional Property of Composite Flour of Water yam and Cowpea

\begin{tabular}{cccccc}
\hline Sample & BD & WAC & OAC & SWI & GT \\
\hline A & $0.74 \pm 0.01^{\mathrm{c}}$ & $2.53 \pm 0.08^{\mathrm{b}}$ & $3.31^{\mathrm{a}} \pm 0.01$ & $0.96^{\mathrm{a}} \pm 0.01$ & $6.75^{\mathrm{b}} \pm 0.07$ \\
\hline B & $0.76 \pm 0.02^{\mathrm{a}}$ & $2.67^{\mathrm{a}} \pm 0.14^{\mathrm{a}}$ & $2.75^{\mathrm{c}} \pm 0.26$ & $0.94^{\mathrm{c}} \pm 0.03$ & $6.55^{\mathrm{d}} \pm 0.06$ \\
\hline C & $0.76 \pm 0.01^{\mathrm{b}}$ & $2.23^{\mathrm{e}} \pm 0.09^{\mathrm{e}}$ & $2.55^{\mathrm{e}} \pm 0.43$ & $0.95^{\mathrm{b}} \pm 0.02$ & $6.56^{\mathrm{c}} \pm 0.08$ \\
\hline D & $0.61 \pm 0.03^{\mathrm{f}}$ & $2.09^{\mathrm{f}} \pm 0.18^{\mathrm{f}}$ & $2.79^{\mathrm{b}} \pm 0.05$ & $0.93^{\mathrm{d}} \pm 0.04$ & $6.45^{\mathrm{e}} \pm 0.21$ \\
\hline E & $0.69 \pm 0.04^{\mathrm{e}}$ & $2.52^{\mathrm{c}} \pm 0.12^{\mathrm{c}}$ & $2.63^{\mathrm{d}} \pm 0.08$ & $0.91^{\mathrm{f}} \pm 0.05$ & $7.35^{\mathrm{a}} \pm 0.05$ \\
F & $0.72 \pm 0.02^{\mathrm{d}}$ & $2.33^{\mathrm{d}} \pm 0.15^{\mathrm{d}}$ & $2.41^{\mathrm{f}} \pm 0.04$ & $0.92^{\mathrm{e}} \pm 0.02$ & $6.41^{\mathrm{f}} \pm 0.09$ \\
\hline
\end{tabular}

Where $\mathrm{A}=100 \%$ water yam flour and $\mathrm{B}=90 \%$ water yam flour and $10 \%$ cowpea flour, $\mathrm{C}=80$ water yam flour and $20 \%$ cowpea flour, $\mathrm{D}=70 \%$ water yam flour and $30 \%$ cowpea flour, $\mathrm{E}=60 \%$ water yam flour and $40 \%$ cowpea flour, $\mathrm{F}=50 \%$ water yam flour and $50 \%$ cowpea flour.

Table 3. Sensory Evaluation of composite flour of water yam and cowpea

\begin{tabular}{|c|c|c|c|c|c|c|}
\hline Sample & Taste & Flavour & Aroma & Texture & Colour & General acceptability \\
\hline A & $6.52 \pm 1.61$ & $6.15 \pm 1.52$ & $6.17 \pm 1.56$ & $6.06 \pm 1.41$ & $6.50 \pm 1.67$ & $6.67 \pm 1.62$ \\
\hline B & $6.53 \pm 0.96$ & $6.59 \pm 1.33$ & $6.59 \pm 1.33$ & $8.32 \pm 1.21$ & $6.65 \pm 1.20$ & $7.25 \pm 1.29$ \\
\hline $\mathrm{C}$ & $6.85 \pm 1.23$ & $6.67 \pm 1.39$ & $6.44 \pm 1.42$ & $6.38 \pm 1.78$ & $6.64 \pm 1.37$ & $6.94 \pm 1.46$ \\
\hline $\mathrm{D}$ & $6.56 \pm 1.89$ & $6.02 \pm 1.96$ & $6.32 \pm 1.96$ & $6.12 \pm 1.75$ & $6.24 \pm 1.60$ & $6.59 \pm 1.74$ \\
\hline $\mathrm{E}$ & $6.46 \pm 076$ & $6.43 \pm 1.26$ & $6.71 \pm 1.31$ & $6.55 \pm 1.61$ & $6.43 \pm 1.56$ & $6.34 \pm 1.32$ \\
\hline $\mathrm{F}$ & $6.23 \pm 1.34$ & $6.33 \pm 1.21$ & $6.23 \pm 1.45$ & $6.22 \pm 1.32$ & $6.32 \pm 1.23$ & $6.46 \pm 1.24$ \\
\hline
\end{tabular}

Where $\mathrm{A}=100 \%$ water yam flour and $\mathrm{B}=90 \%$ water yam flour and $10 \%$ cowpea flour, $\mathrm{C}=80$ water yam flour and $20 \%$ cowpea flour, $\mathrm{D}=70 \%$ water yam flour and $30 \%$ cowpea flour, $\mathrm{E}=60 \%$ water yam flour and $40 \%$ cowpea flour, $\mathrm{F}=50 \%$ water yam flour and $50 \%$ cowpea flour. 


\section{Conclusions}

The taste of the samples became sweeter with substitution as compared to $60: 40 \%$ and 70:30\% which had better taste. Sample $100 \%$ had the least taste, flavour and aroma due to no quantity of cowpea flour is contained. The textures of the flours were different due to the quantity of cowpea flour that was added to each of the sample. But sample $80 / 20 \%$ have the highest taste, flavour, and colour, which indicates that cowpea flour substitute in water yam flour, cannot be less than $20 \%$ cowpea flour because of nutritional balance. Generally the substitution of water yam flour with cowpea flour had led to high protein content, fiber content, mineral content and energy, which shows that, it had increase the nutritional quality and health benefit of people and should be encouraged as source of protein with numerous health benefits.

\section{REFERENCES}

[1] Adamson I.(1985),. Dietary fibre of yam and cassava In: Advances in Food research, (ed.) Osuji, Pp. 321-340.

[2] Adebowale, A.A., Sanni, L.O.,Awonorin, S.O,. (2005). Effects of texture modifiers on the physicochemical and sensory properties of dried fufu. Food Sci. Tech. Intl., 11(5),373- 382 .

[3] AOAC,. (2000) official methods of aanalysis of A.O.A.C. international (17th ed).Washington, DC:

[4] AOAC, (2005) official methods of aanalysis of A.O.A.C. international (18th ed). Washington, DC:

[5] Asare AT, Agbemafle R, Adukpo GE., Diabor E, and Adamtey KA (2013) Assessment of functional properties and Nutritional composition of some cowpea (Vigna Unguiculata L.) genotype in Ghana. ARPN Journal of Agricultural and Biological Science. 8: 465-469.

[6] Baah, F.D., Maziya-Dixon, B., Asiedu, R., Oduro, I., and Ellis, W.O. (2009). Physicochemical and pasting characterisation of water yam (Dioscorea spp.) and relationship with eating quality of pounded yam. Journal of Food, Agriculture and Environment, 7(2),107-112.

[7] Chou, D. H. and Morr, C. V. (1979). Protein-water interactions and functional properties. Journal of American Oil Chemists Society 56: 534.

[8] Egounlety M; Aworh O.C; Akingbala T.O, Hooben A.I and Nago M.C (2002). Nutritional and sensory evaluation of Tempe fortified maize based weaning foods. International Journal of food Sciences and Nutrition. 53. 15-27.

[9] Ekariko. P,. (2005) Akara: The Fast Food with a Painstaking Preparation. Afrique 16:14.

[10] FAO,. (2000). Food and Agricultural Organization, Food balance sheet. http:/FAO.Org/Lim500/wrap.pl. Accessed 19th July, 2002

[11] Henshaw, F.O,. Sobowale, M.K,. (1996) cowpea flour produced from different bean varieties: functional properties, composition and acceptability of products. Nigerian food journal 14: 62-70

[12] Hoover, R. (2001). Composition, molecular structure and physicochemical properties of tuber and root starches. Carbohydrate Polymers, 45, 253 - 267.

[13] Iheokoronye, A. and Ngoddy, P. (1985). Integrate food science and technology for the tropics. McMillan pub. Ltd. London.

[14] Karuna, D., Kulkarni, D. N. and Ingle, U. M. (1996). Fractionation, solubility and functional properties of cowpea (Vigna unguiculata) proteins as affected by $\mathrm{pH}$ and/or salt concentration. Journal of Food Chemistry 82: 207-212.

[15] Kordylas, J. M. (1990). Processing and Preservation of tropical and subtropical foods. Macmillan Publishers Ltd, London and Basingstoke. 1-374.

[16] Kulkarni, K. D., Kulkarni, D. N. and Ingle, U. M. (1991). Sorghum malted-based weaning formulations: preparation, functional properties and nutritive value. Food and Nutrition Bulletin 13(4): 322-327.

[17] Ngoddy PO, Enwere NJ, and Onurah VI (1986) Cowpea flour performance in Akara and moi-moi preparations. Tropical science 26: $101-119$.

[18] Odedeji JO, Oyeleke WA (2011) Proximate, physicochemical and organoleptic properties of whole and dehulled cowpea seed flour (vigna unguiculata). Pakistan journal of nutrition $10: 1175-1178$.

[19] Olu M, Ogunyele OAB, Adekoyeni OO, Jimoh O, Oluwajoba SO, Sobanwa MO (2012)Rheological and functional properties of soy-pondo yam flour. International journal of food science and nutrition engineering. $2: 101-$ 107.

[20] Onayemi O., and Potter N. N,. (1974). Preparation and storage properties of drum dried white yam (Dioscorea rotundata Poir) flakes. J. Food Sci. 39:539-541.

[21] Onwuka G. I., and Ihuma C.. (2007). Physicochemical composition and product behaviour of flour and chips from two yam spp. (Dioscorea rotundata and Dioscorea alata). Res. J. Appl. Sci. 2:35-38.

[22] Ragaee S., Abdel - Aal E.M (2006). "Pasting Properties of Starch and Protein in Selected Cereals and Quality of their Food Products''. Food chem. 95;9 - 18.

[23] S. Shanthakumari, V.R. Mohan, John de Britto (2008). Nutritional evaluation and germination of toxic principles in wild yam (Dioscorea spp). Tropical and Sub-tropical Agrosystems 8,319-325.

[24] Sanni A.I., Ohilude, A.A. and Ibidapo O.T. (2001). Biochemical composition of infant weaning food fabricated from fermented blends of cereal and soy beans. Food chem. 65: $35-39$.

[25] Sosulki, F.W (1962). The Centrifuge Method for Determining Flour Absorptivity in Hardened Spring Wheat's Cereal Chemistry. 39: 344

[26] SPSS 16.0 (2008) Statistical Package for the social science. Command syntax Reference. Inc. Chicago III. 
[27] Udensi E. A., Oselebe H. O., and Iweala O. O,. (2008). The Investigation of chemical composition and functional properties of water yam (D.alata): effect of varietal differences. J. Nut. 7:342-344.

[28] Ugwu FM. The potentials of roots and tubers as wearing foods. Parkistan Journal of Nutrition. 2009; 8:1701-1705

[29] Walter, W.M., Truong, V.D., and Wiesenborn, D.P., Carvajal, P. (2000). Rheological and Physico chemical Properties of starches from Moist and Dry-type Sweet potatoes. Journal of Agric Food Chem. 48, 2937-2942. 